\title{
SEASONAL VARIATION IN VOLUNTARY FOOD INTAKE AND POST-WEANING GROWTH IN LAMBS: A COMPARISON OF GENOTYPES
}

\author{
G. R. IASON AND A. R. MANTECON \\ Macaulay Land Use Research Institute, Pentlandfield, Roslin, Midlothian EH25 9RF
}

\section{ABSTRACT}

Voluntary food intake (VFI) was measured daily and live weight (LW) was measured weekly in a total of 39 growing lambs of six genotypes given a similar complete chopped-straw based diet in experiments in 1983, 1985, 1987 and 1988. The six genotypes and the years of study were: Scottish Blackface (BF), 1983 and 1988; Suffolk $\times$ (Border Leicester $\times$ BF) $(\mathrm{BL} \times \mathrm{BF})$, Suffolk $\times$ (East Friesland $\times$ Cheviot $)(\mathrm{EF} \times \mathrm{NCC})$, Suffolk $\times$ (East Friesland $\times$ BF $)(\mathrm{EF} \times \mathrm{BF})$, 1985; Welsh mountain (WM) and Beulah (BH), 1985. Measurements were made on lambs penned individually within 6 weeks of weaning at 5 to 6 months of age through to slaughter in the following spring. During this period there was an increase in LW and VFI associated with growth. Regression lines were fitted to LW and weekly means of daily VFI against week for each individual. Analysis of deviations about these lines showed a decline in VFI in BF lambs around December and to a lesser extent in BL $\times$ BF from December to January. The decline in VFI in BF was observed in two different years. A negative deviation from the normal rate of increase in LW was also apparent although it was much less marked and present in $\mathrm{EF} \times \mathrm{NCC}$ lambs as well as $\mathrm{BF}$ and $\mathrm{BF} \times \mathrm{NCC}$. Any such variability of seasonal cycles between genotypes of growing lamb would influence the extent to which nutrition and growth may be manipulated. This should be considered when choosing a feeding or growth regime for a particular genotype, or vice versa.

KEYWORDS: food intake, growth, lambs, seasonality.

\section{INTRODUCTION}

IN both sheep and deer, a seasonal depression in voluntary food intake (VFI) has been observed, such that the nadir of the annual cycle occurs in winter (Kay, 1979; Blaxter, Fowler and Gill, 1982). This possibly represents an adaptation among some temperate and high latitude species to a predictable seasonal decline in food availability or quality (Kay and Staines, 1981; Kay, 1985). This decline in intake may be accompanied by a concomittant depression in fasting metabolic rate in winter (Silver, Colovos, Holter and Hayes, 1969; Blaxter and Boyne, 1982). The annual cycle of VFI is entrained by photoperiod and is reported to vary between genotypes of sheep, although only few have been studied (Kay, 1979 and 1985). The food requirements of animals on similar diets is normally considered to be a function of live weight (LW) or metabolic body weight.
However, if different genotypes have different propensities for a natural depression in VFI in winter, then this may need to be considered when determining their food requirements. The first aim of this study was to describe and compare the pattern of VFI in winter by growing lambs of six different genotypes.

Among deer species of high northern latitudes, winter depression of appetite is associated with a period of depression in growth in LW (Wood, Cowan and Nordan, 1962). The second aim of this study was to compare the extent of any seasonal depression of growth in LW of ad libitum fed lambs of six hill and upland genotypes.

\section{MATERIAL AND METHODS}

\section{Livestock and treatments}

In 1983, 1985, 1987 and 1988 indoor feeding experiments were conducted at the Bush Estate, Midlothian, Scotland (latitude 
$55^{\circ} 50^{\prime} \mathrm{N}$, longitude $3^{\circ} 11^{\prime} \mathrm{E}$ ) with castrated male lambs. In each year, lambs from one or more of six commercially produced genotypes were drawn from flocks in hill or upland areas of Britain in which birth and weaning took place in April and August respectively (Table 1). All lambs were thus of a similar age when first housed in the late summer or autumn. Each was housed in an individual pen under natural daylight and temperature regimes. In years 1983, 1987 and 1988, the same chopped straw-based complete pelleted diet was offered (dry matter (DM) $870 \mathrm{~g} / \mathrm{kg}$, crude protein (CP) $122 \mathrm{~g} / \mathrm{kg}$ DM, metabolizable energy (ME) $10.4 \mathrm{MJ} / \mathrm{kg}$ DM; see Doney, Milne, Maxwell, Sibbald and Smith, 1988). In 1985, when three genotypes were compared simultaneously, a similar pelleted chopped straw-based complete diet was used (DM $870 \mathrm{~g} / \mathrm{kg}$, CP $150 \mathrm{~g} / \mathrm{kg}$ DM, ME $10.6 \mathrm{MJ} / \mathrm{kg} \mathrm{DM})$. This diet had similar constituents and the same proportion of chopped straw $(150 \mathrm{~g} / \mathrm{kg} \mathrm{DM})$ as that used in other years but the added fish meal increased the total CP. Data reported here derive from 39 lambs fed ad libitum for which VFI was measured daily and LW weekly. Measurements began 2 weeks after first penning (Table 1) and continued until slaughter in the following spring. This regime was followed in all genotypes and years except for the BF lambs in 1988 when they were slaughtered relatively early in February. The 'mature' LW was defined as the LW of lambs over 1 year old which had stabilized for a period of 4 weeks.

\section{Statistical analyses}

To permit comparisons between years using standard dates, weeks were numbered consecutively from 1 August onwards. The data used in this analysis were restricted to the period mid November (week 15) to the end of May (week 44) for which data were available for all six genotypes in the 1983 to 1987 experiments. Preliminary analysis showed that during this period (weeks 15 to 44) the main effects explaining variation in both VFI and LW were (i) an overall increase with time, and (ii) a difference between genotypes. The between-genotype difference was due to differences in rate of live-weight gain (LWG g/day), and the consequent effect on rate of increase of VFI with time, rather than to differences in initial size of lambs. The precise form of the increase in LW or VFI with time varied between individual lambs. None of the standard growth models was applicable to all individuals and hence the approach adopted was to fit linear regressions to VFI or LW $v$. week, for each individual lamb, and

TABLE 1

The source and genotypes of experimental lambs, their month and year of birth and experimental dates

\begin{tabular}{|c|c|c|c|c|}
\hline Genotype & Abbreviation & $\begin{array}{l}\text { Month and } \\
\text { year of birth } \dagger\end{array}$ & $\begin{array}{l}\text { Date first } \\
\text { penned }\end{array}$ & Source of livestock \\
\hline Scottish Blackface & $\mathrm{BF}$ & 4.83 (late) & 6.9 .83 & $\begin{array}{l}\text { MLURI, Sourhope Research Station, } \\
\text { Roxburgh }\end{array}$ \\
\hline Scottish Blackface & $\mathrm{BF}$ & 4.88 (late) & 27.8 .88 & $\begin{array}{l}\text { MLURI, Glensaugh Research Station, } \\
\text { Kincardine }\end{array}$ \\
\hline \multicolumn{5}{|l|}{$\begin{array}{l}\text { Suffolk } \times \text { (Border } \\
\text { Leicester } \times \text { Scottish }\end{array}$} \\
\hline Blackface) & $\mathrm{BL} \times \mathrm{BF}$ & 4.85 (late) & 8.10 .85 & Tweeddale \\
\hline \multicolumn{5}{|l|}{ Suffolk $\times$ (East } \\
\hline Friesland $\times$ Cheviot) & $\mathrm{EF} \times \mathrm{NCC}$ & 4.85 (late) & 8.10 .85 & \\
\hline $\begin{array}{l}\text { Suffolk } \times \text { (East } \\
\text { Friesland } \times \text { Scottish } \\
\text { Blackface }\end{array}$ & $\mathrm{EF} \times \mathrm{BF}$ & 4.85 (late) & 8.10 .85 & $\begin{array}{l}\text { MLURI, Glensaugh Research Station, } \\
\text { Kincardine }\end{array}$ \\
\hline Welsh Mountain & WM & 4.87 (early) & 31.8 .87 & Dyfed \\
\hline Beulah & $\mathrm{BH}$ & 4.87 (early) & 31.8 .87 & Powys \\
\hline
\end{tabular}

$\dagger$ First or second half of month given in parentheses. 
compare the patterns of deviations from this general model. The slope (b) and the intercept (a) parameters of the regression lines: $Y=a+b T$ where $T=$ time (weeks) and $Y=\mathrm{LW}(\mathrm{kg})$ or VFI $(\mathrm{g})$ were analysed by analysis of variance to identify any differences between genotypes. This procedure eliminated the statistical problem of nonindependence of successive weekly measures of these variables which were obtained from the same individual (Rowell and Walters, 1976). The regression lines of VFI and LW against week for Scottish Blackface (BF) lambs in 1988 were not strictly comparable with those from experiments in other years due to the measurements spanning a different set of weeks i.e. 7 to 26. These data were excluded from the analyses of variance with other genotypes and data for VFI are presented separately.

Patterns of seasonal variation in VFI and LW and differences in seasonal pattern between genotypes were investigated by analysis of deviations about each individual regression line. A tendency for deviations which were consistently negative or positive at a particular season would indicate seasonal variability in the measurement. For each of these variables, deviations from each individual lamb's line were averaged within 10 3-week periods. This procedure minimized type 1 statistical error (Sokal and Rohlf, 1981 ) by comparing patterns of 10 rather than 30 sets of deviations. Differences between genotypes in the seasonal pattern of these deviations were quantified by analysis of variance. The weekly mean of the mean daily temperatures recorded at the local meterological station at Bush Estate $(0.5 \mathrm{~km}$ from the experimental building), were used to compare the temperature patterns between years. The pattern of change of temperatures in weeks 15 to 44 in the 3 years used in the between-year analyses were compared using Kendall's coefficient of concordance (Siegel, 1956).

RESULTS

Seasonal variation in voluntary food intake

Much of the variation in daily VFI on a given date was explained by the $\mathrm{LW}$ of the lambs e.g. week 30: VFI $=2686+$ $184.96 \mathrm{LW}, r^{2}=0.55$, no. $=36$, residual s.d. $=1712$.

The parameters for the linear increases in daily VFI from week 15 (mid November) to week 44 (late May) were calculated for each genotype of lamb (Table 2). The rate at which the daily VFI increased during this period varied significantly between genotypes from $31.9 \mathrm{~g} /$ day in $B F$ to only $11 \mathrm{~g} /$ day in Beulah $(\mathrm{BH})$. Deviations from the regression lines of VFI $v$. week, for each individual lamb, showed a clear pattern which varied between genotypes (Figure 1). There was a significant interaction between lamb genotype and time period; the mean deviations from the fitted lines were significantly $(P<0.05)$ different between genotypes in the weeks 15 to 17 and 21 to 23 (Figure 1). The purebred BF lambs in the 1983 experiment

TABLE 2

The mean rate of increase of voluntary food intake (VFI, g/day) calculated from regression of VFI against week (VFI $=\mathrm{a}+\mathrm{bT}$ ) for each lamb genotype, and estimates of VFI in weeks 15 to 30

\begin{tabular}{|c|c|c|c|c|c|c|c|c|}
\hline & \multicolumn{6}{|c|}{ Genotype } & \multirow[b]{2}{*}{ s.e.d } & \multirow[b]{2}{*}{ Significance } \\
\hline & $\mathrm{BF}$ & $\mathrm{BL} \times \mathrm{BF}$ & $\mathrm{EF} \times \mathrm{NCC}$ & $\mathrm{EF} \times \mathrm{BF}$ & WM & $\mathrm{BH}$ & & \\
\hline No. of lambs & 10 & 6 & 5 & 5 & 4 & 6 & & \\
\hline $\begin{array}{l}b \text { (g/day) } \\
\text { VFI week } 15\end{array}$ & 31.9 & $25 \cdot 7$ & $21 \cdot 6$ & $19 \cdot 0$ & $16 \cdot 6$ & $11 \cdot 1$ & $7 \cdot 2$ & * \\
\hline $\begin{array}{l}\text { (g/kg LW } \\
\text { per day) } \\
\text { VFI week } 30\end{array}$ & $42 \cdot 5$ & $36 \cdot 6$ & 37.4 & 39.9 & $38 \cdot 8$ & $45 \cdot 7$ & $3 \cdot 2$ & * \\
\hline $\begin{array}{l}\text { (g/kg LW } \\
\text { per day) }\end{array}$ & $35 \cdot 5$ & $29 \cdot 1$ & $29 \cdot 3$ & $29 \cdot 8$ & $32 \cdot 8$ & $35 \cdot 7$ & $1 \cdot 3$ & $* * *$ \\
\hline
\end{tabular}




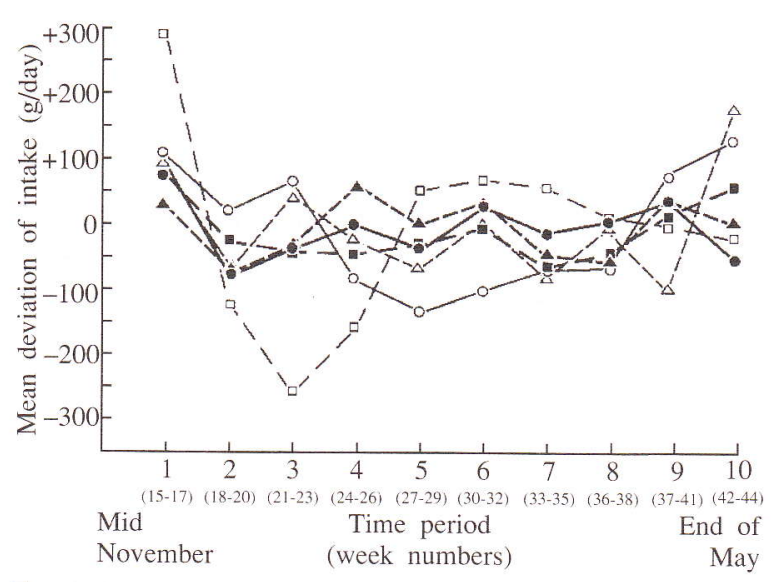

FIG, 1. The mean deviation from regression lines for each lamb of voluntary food intake against week, for each of the six genotypes: $\mathrm{BF}(\square), \mathrm{EF} \times \mathrm{BF}(\Delta), \mathrm{BL} \times \mathrm{BF}(\bigcirc), \mathrm{EF} \times$

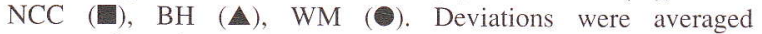
across 3-week periods. Significant differences between genotypes within 3-week periods are indicated.

showed a strong negative deviation in VFI from the overall trend, in November through until late December. These negative deviations were due to an actual decrease in VFI in this genotype at this time. This was confirmed in the BF lambs in the 1988 experiment in which the VFI of two of the three individuals also declined at around this season whilst the third lamb showed only a reduction in the rate of increase of VFI (Figure 2). The crossbred lambs from Border Leicester (BL) $\times$ BF ewes showed a low amplitude cycle of intake, the trough of which was some 6 weeks later than that of the BF lambs (Figure 1).

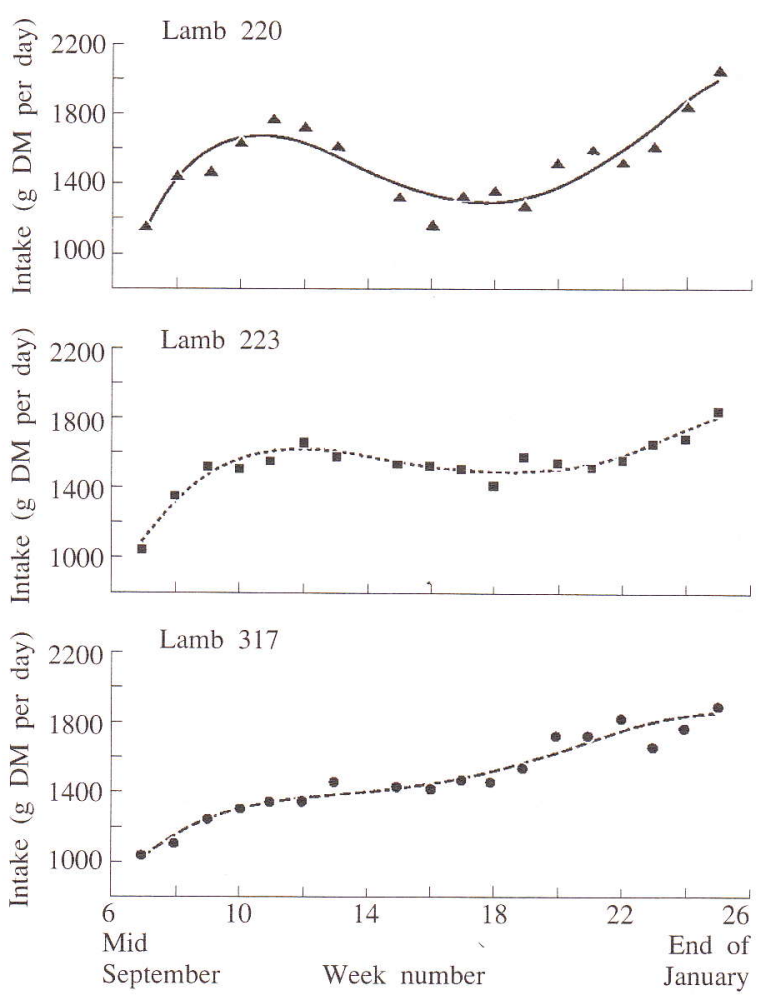

FIG. 2. Variations in voluntary food intake of the three BF lambs in 1988 from weeks 6 to 26. The fitted curves are fourth order polynomials, the quartic term explains a significant proportion of the variation $(P<0.05)$ in all cases except lamb 317.

\section{Seasonal variation in $L W$}

Different absolute rates of LWG (b) meant that by week 30, differences between genotypes in LW were considerable (Table 3). The differences between the mean

\section{TABLE 3}

Mean parameters of regression lines of live weight ( $L W)$ against week $(L W=\mathrm{a}+\mathrm{bT})$ for each lamb genotype and estimates of LW in weeks 15 to $30^{\circ}$

\begin{tabular}{|c|c|c|c|c|c|c|c|c|}
\hline & \multicolumn{6}{|c|}{ Genotype } & \multirow[b]{2}{*}{ s.e.d } & \multirow[b]{2}{*}{ Significance } \\
\hline & $\mathrm{BF}$ & $\mathrm{BL} \times \mathrm{BF}$ & $\mathrm{EF} \times \mathrm{NCC}$ & $\mathrm{EF} \times \mathrm{BF}$ & WM & $\mathrm{BH}$ & & \\
\hline$a(\mathrm{~kg})$ & $11 \cdot 6$ & $16 \cdot 4$ & $15 \cdot 5$ & $16 \cdot 4$ & $16 \cdot 0$ & 16.9 & 2.95 & \\
\hline$b$ (g/day) & 191 & 220 & 211 & 216 & 121 & 129 & 21 & $* * *$ \\
\hline $\mathrm{LW}$ week $15(\mathrm{~kg})$ & $31 \cdot 7$ & $39 \cdot 5$ & $37 \cdot 6$ & $39 \cdot 0$ & 28.7 & $30 \cdot 5$ & $2 \cdot 49$ & $* * *$ \\
\hline LW week $30(\mathrm{~kg})$ & $51 \cdot 7$ & $62 \cdot 6$ & $59 \cdot 8$ & 61.7 & 41.4 & $44 \cdot 0$ & 3.62 & $* * *$ \\
\hline \multicolumn{9}{|c|}{ Proportion of mature } \\
\hline LW at week 15 & 0.43 & 0.43 & $0 \cdot 46$ & 0.45 & 0.57 & 0.51 & & \\
\hline
\end{tabular}

† Sample sizes as in Table 2. 


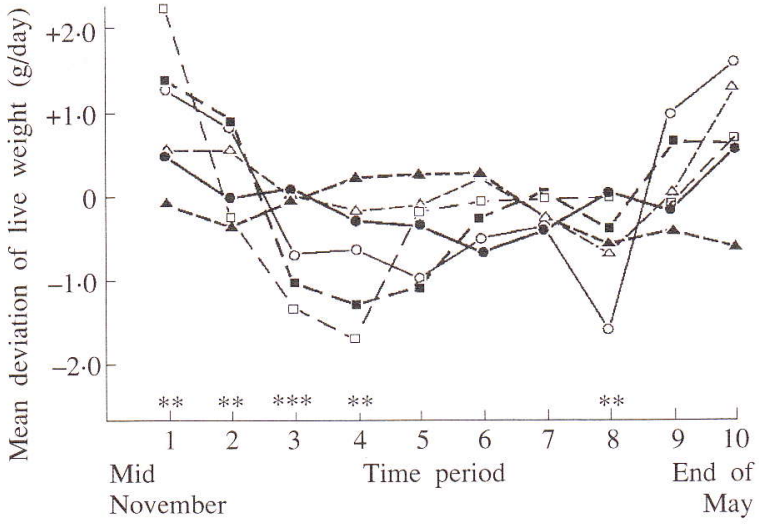

FIG. 3. The mean deviation from regression lines for each lamb of live weight against week, for each of the six genotypes: $\mathrm{BF}(\square), \mathrm{EF} \times \mathrm{BF}(\Delta), \mathrm{BL} \times \mathrm{BF}(\bigcirc), \mathrm{EF} \times$

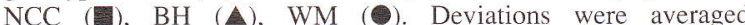
across 3-week periods. Significant differences between genotypes within 3-week periods are indicated. Time periods correspond to week numbers in Figure 1.

deviations in LW for the lambs were significant between genotypes in the first four and the eighth of the 10 3-week periods. The LW of the BF and the East Friesland $\times$ North Country Cheviot $(\mathrm{EF} \times \mathrm{NCC})$ lambs deviated consistently in a negative manner to their fitted regressions between weeks 18 to 26 and 21 to 29 respectively, whilst the $\mathrm{BL} \times \mathrm{BF}$ lambs' deviations were strongly negative during weeks 21 to 38 (Figure 3).

Seasonal and yearly variation in temperature

The 7-day means of the mean daily temperatures in weeks 15 to 44 were highly concordant between years $\left(W=0.707, \chi^{2}=\right.$ 61.50, $P<0.001$; Siegel, 1956) i.e. there was no difference in the pattern of change of mean weekly temperatures in different years. There was no exceptional change in temperature in weeks 18 to 26 of 1983 , or weeks 15 to 20 of 1988 when the intake depression of the $\mathrm{BF}$ lambs was greatest.

\section{DISCUSSION}

There was a strong depression of VFI in the purebred BF lambs from mid November to late December in both 1983 and 1988 . The $\mathrm{BL} \times \mathrm{BF}$ crossbred lambs also showed a depression in VFI relative to the expected increase associated with increasing LW. Although only the depression in VFI in the $\mathrm{BF}$ genotype was confirmed in separate years, the results clearly lead to the hypothesis that different genotypes of lamb vary in their seasonal pattern of VFI. This overall pattern of a depression of VFI in winter by the BF genotype is contrary to the increase in VFI that would be anticipated were the lower ambient temperatures the most important variables determining seasonal pattern of intake. The remaining four genotypes of lamb showed constant increases in VFI throughout the winter which were associated with their approximately linear growth trajectory. A survey of the literature showed five genotypes in which VFI declined seasonally, these were Suffolk $X$ Finn-Dorset, Soay, Cheviot, Scottish Blackface and Shetland (Gordon, 1964; Tarttelin, 1968; Milne, MacRae, Spence and Wilson, 1978), Kay, 1979; Blaxter et al., 1982). These are mainly hill, upland or high latitude genotypes. It might thus have been predicted that both $\mathrm{BF}$ and Welsh Mountain (WM) lambs, both hill genotypes, would have shown the most marked pattern of depression in VFI due to the harshness of their winter environment (Kay, 1985). However, the absence of a depression in intake of WM lambs suggests that no such generalization can be made for hill sheep although care must be taken when drawing general conclusions about genotypes from small numbers of individuals from a single source.

The seasonal periodicity in the growth of captive deer and free-living ruminants is well documented (Wood et al., 1962; LeaderWilliams and Ricketts, 1981; Suttie and Hamilton, 1983). In the sheep in this experiment, where depression in LWG occurred, it was only very slight; the greatest negative deviation was $1.66 \mathrm{~kg}$, which is within the range that could be explained by a reduction in gut fill resulting from lower intakes (Milne et al., 1978). This implies that growth in body tissue may have continued along the same general linear trend despite reduced VFI.

Growth of lambs might be expected to be sigmoidal and growth and VFI should vary between genotypes of sheep according to 
their mature LW and with stage of maturity (McClelland, Bonaiti and Taylor, 1976; Thonney, Taylor, Murray and McClelland, 1987). In the early stages of the sampling period in November and December the LW and VFI of BF lambs deviated consistently negatively from the linear regression of these variables against time. It is not possible to explain these results for $\mathrm{BF}$ in terms of them being at a different stage of maturity than the other genotypes; in week 15 all genotypes were at a similar proportion of maturity, four of them including BF being almost identical (Table 3). One study comparing genotypes offered a complete diet ad libitum found that these nutritional conditions sustained growth at near maximum rates over a broad range of proportions of maturity (Thonney et al., 1987). This may explain the general suitability of the linear model for describing the change of LW and VFI with time in growing lambs.

Where a seasonal decline has been measured in sheep across several years, the amplitude of the VFI cycle is greatest during the 1st year of life (Blaxter et al., 1982). Since lambs are usually slaughtered during their 1st year at a relatively small proportion of adult body weight, there are several implications of a seasonal cycle in VFI for the manipulation of growth. If VFI, basal metabolic rate or growth potential of a growing animal enter a trough then it may be difficult to enforce a rapid growth period at his time. Furthermore, if growth or carcass conformation is to be controlled, perhaps by a period of food restriction followed by compensatory growth, then the timing of food restriction relative to any natural depression of intake must be considered. For domestic ruminants, an expected intake required for normal growth can be calculated according to published recommended guidelines (Agricultural Research Council, 1980). Should a restriction be applied as a percentage reduction from this level, then among animals with a natural depression of intake, restriction may only be apparent rather than real. When seeking accurate predictions of the effect of nutritional treatments on growth, full account must be taken of natural seasonal variation in intake.

\section{ACKNOWLEDGEMENTS}

We thank J. A. Milne, I. A. Wright and an anonymous referee for advice and criticism, E. A. Hunter for statistical help and A. D. M. Smith for maintenance of records.

\section{REFERENCES}

Agricultural Research Council. 1980. The Nutrient Requirements of Ruminant Livestock. CAB. Slough.

Blaxter, K. L. and Boyne, A. W. 1982. Fasting and maintenance metabolism of sheep. Journal of Agricultural Science, Cambridge 99: 611-620.

Blaxter, K. L., Fowler, V. R. and Gill, J. C. 1982. A study of the growth of sheep to maturity. Journal of Agricultural Science, Cambridge 98: 405-420.

Doney, J. M., Milne, J. A., Maxwell, T. J., Sibbald, A. M. and Smith, A. D. M. 1988. The effects of live weight at weaning on growth rate and carcass composition at different stages of maturity in Scottish Blackface lambs fed on two different diets. Animal Production 47: 401-409.

Gordon, J. G. 1964. The effect of time of year on the roughage intake of housed sheep. Nature, London 204: 798-799.

KAY, R. N. B. 1979. Seasonal change of appetite in deer and sheep. ARC Research Reviews 5: 13-15.

KAY, R. N. B. 1985. Seasonal variation of appetite in ruminants. In Recent Advances in Animal Nutrition (ed. W. Haresign), pp. 113-129. Butterworths, London.

KAy, R. N. B. and Staines, B. W. 1981. The nutrition of the red deer (Cervus elaphus). Nutrition Abstracts and Reviews - Series B51: 601-622.

Leader-Williams, N. and Ricketts, C. 1981. Seasonal and sexual patterns of growth and condition of reindeer introduced into S. Georgia. Oikos 38: 27-39.

McClelland, T. H., Bonaiti, B. and Taylor, St C. S. 1976. Breed differences in body composition of equally mature sheep. Animal Production 23: 281-293.

Milne, J. A., Macrae, J. C., Spence, A. M. and WILSON, S. 1978. A comparison of the voluntary intake and digestion of a range of forages at different times of the year by sheep and red deer (Cervus elaphus). British Journal of Nutrition 40: 347-357.

Rowell, J. G. and Walters, D. E. 1976. Analysing data with repeated observations on each experimental unit. Journal of Agricultural Science, Cambridge 87: 423-432.

Siegel, S. 1956. Non-parametric Statistics for the Behavioural Sciences. McGraw-Hill, Kogakusha, Tokyo.

Silver, H., Colovos, N. F., Holter, J. B. and Hayes, H. H. 1969. Fasting metabolism of white-tailed deer. Journal of Wildlife Management 33: 490-498.

SOKAL, R. R. and RoHLF, F. J. 1981. Biometry: the Principles and Practice of Statistics in Biological Research. Freeman, San Francisco.

Suttie, J. M. and Hamilton, W. J. 1983. The effect of winter nutrition on growth of young Scottish red deer. Journal of Zoology, London 201: 153-159. 
Tarttelin, M. F. 1968. Cyclical variations in food and water intake in ewes. Proceedings of the Physiological Society 194: 29-31P.

Thonney, M. L., Taylor, St C. S., Murray, J. I. and McClelland, T. M. 1987. Breed and sex differences in equally mature sheep and goats. 2. Body components at slaughter. Animal Production 45: 261-276
WoOd, A. J., Cowan, I. MCT. and Nordan, H. C. 1962. Periodicity of growth in ungulates as shown by deer of the genus Odocoileus. Canadian Journal of Zoology 40: 593-603.

(Received 4 April 1990 - Accepted 20 August 1990) 